\title{
Reconstruction of Tertiary progradation and clinoform development on the New Jersey passive margin by 2-D backstripping
}

\author{
Michael S. Steckler ${ }^{\mathrm{a}, *}$, Gregory S. Mountain ${ }^{\mathrm{a}}$, Kenneth G. Miller ${ }^{\mathrm{b}, \mathrm{a}}$, Nicholas Christie-Blick ${ }^{\mathrm{a}}$ \\ ${ }^{a}$ Lamont-Doherty Earth Observatory, Palisades, NY 10964, USA \\ ${ }^{b}$ Department of Geological Sciences, Rutgers University, Piscataway, NJ 08855, USA
}

Received 13 March 1997; accepted 10 April 1998

\begin{abstract}
We have reconstructed the Oligocene to Middle Miocene paleobathymetry and stratigraphy of the New Jersey margin using a modified backstripping technique. By analyzing the geometry of the margin through time, we investigate its response to fluctuating sea level, changing climate, and variable sediment supply during the Tertiary. The reconstructions reveal a change in the margin morphology from a more steeply dipping $(1: 300$ to $1: 500)$ carbonate ramp in the Eocene to a flatter shelf with a sharp shelf edge at present. This was accomplished by an increase in the terrigenous sediment supply that filled available accommodation and caused progradation across the margin. We link the increase in sediment flux with climatic cooling rather than tectonic processes. The progradation is evidenced by a series of clinoforms whose formation was modulated by sea level and which extend over $100 \mathrm{~km}$ across the shelf. The height and dip of the clinoforms increased as they extended onto the deeper parts of the earlier ramp. The Miocene clinoform rollovers at the New Jersey margin had water depths of $\sim 60-130 \mathrm{~m}$ and are interpreted as the edge of a new continental shelf built over the older ramp. Sea-level fall was probably insufficient to drive the Miocene shorelines past the shelf breaks. Thus, measurements of sea-level amplitude based upon 'coastal' onlap over the clinoforms are not reliable. () 1999 Elsevier Science B.V. All rights reserved.
\end{abstract}

Keywords: continental margins; backstripping; sequence stratigraphy; sea level; clinoform; Tertiary climate

\section{Introduction}

The Neogene stratigraphy of the New Jersey continental margin is characterized by a series of forestepping sequences with well developed clinoforms. The clinoforms extend across the New Jersey margin for over $100 \mathrm{~km}$ and have been well imaged through several generations of seismic-reflection profiling (e.g., Schlee, 1981; Poag, 1985; Greenlee and Moore, 1988; Miller and Mountain, 1994; Austin et al., 1996). The Oligocene to Pleistocene

\footnotetext{
$\bar{*}$ Corresponding author. E-mail: steckler@1deo.columbia.edu
}

succession of thick unconformity-bound sequences is relatively complete. Locally, high sediment accumulation rates developed $(>30 \mathrm{~cm} / \mathrm{ka}$, exceeding $100 \mathrm{~cm} / \mathrm{ka}$ in some sections) as the prograding sequences shingled across a shelf that had been sediment-starved in the Late Cretaceous to early Cenozoic. In conceptual models of the response of margins to sea-level change (Posamentier et al., 1988; Van Wagoner et al., 1990), strata bound by clinoform surfaces, such as those observed on the New Jersey margin, are basic building blocks of siliciclastic sequences. As a result, the sequences containing prominent clinoforms have made the New Jersey 
margin a focus of numerous studies investigating sequence formation and sea-level change.

The depositional sequences across the New Jersey margin have been identified and mapped by a number of authors (e.g., Poag and Schlee, 1984; Poag, 1985; Greenlee et al., 1992; Miller and Mountain, 1994). Greenlee and Moore (1988) and Greenlee et al. (1992) used multichannel seismic data and commercial boreholes to identify Oligocene and Miocene sequences across the New Jersey margin. They attempted to refine the Haq et al. $(1987,1988)$ sea-level curve using the New Jersey record. In 1990, the R/V Maurice Ewing (cruise 9009) col- lected $3750 \mathrm{~km}$ of single-channel and multichannel seismic lines over the New Jersey margin (Fig. 1). This grid became the basis for drilling on the upper continental slope during the Ocean Drilling Program (ODP) Leg 150 (Mountain et al., 1994; Mountain et al., 1996b). Complementary drilling on land by Leg 150X (Miller et al., 1994, 1996) provided updip sampling of the Oligocene-Miocene sequences. In 1995, the R/V Oceanus augmented the seismic data sets by collecting high-resolution multichannel seismic data, including detailed hazard surveys around proposed drilling sites. During 1997, ODP Leg 174A drilled into the sequences on the shelf (Austin et al.,

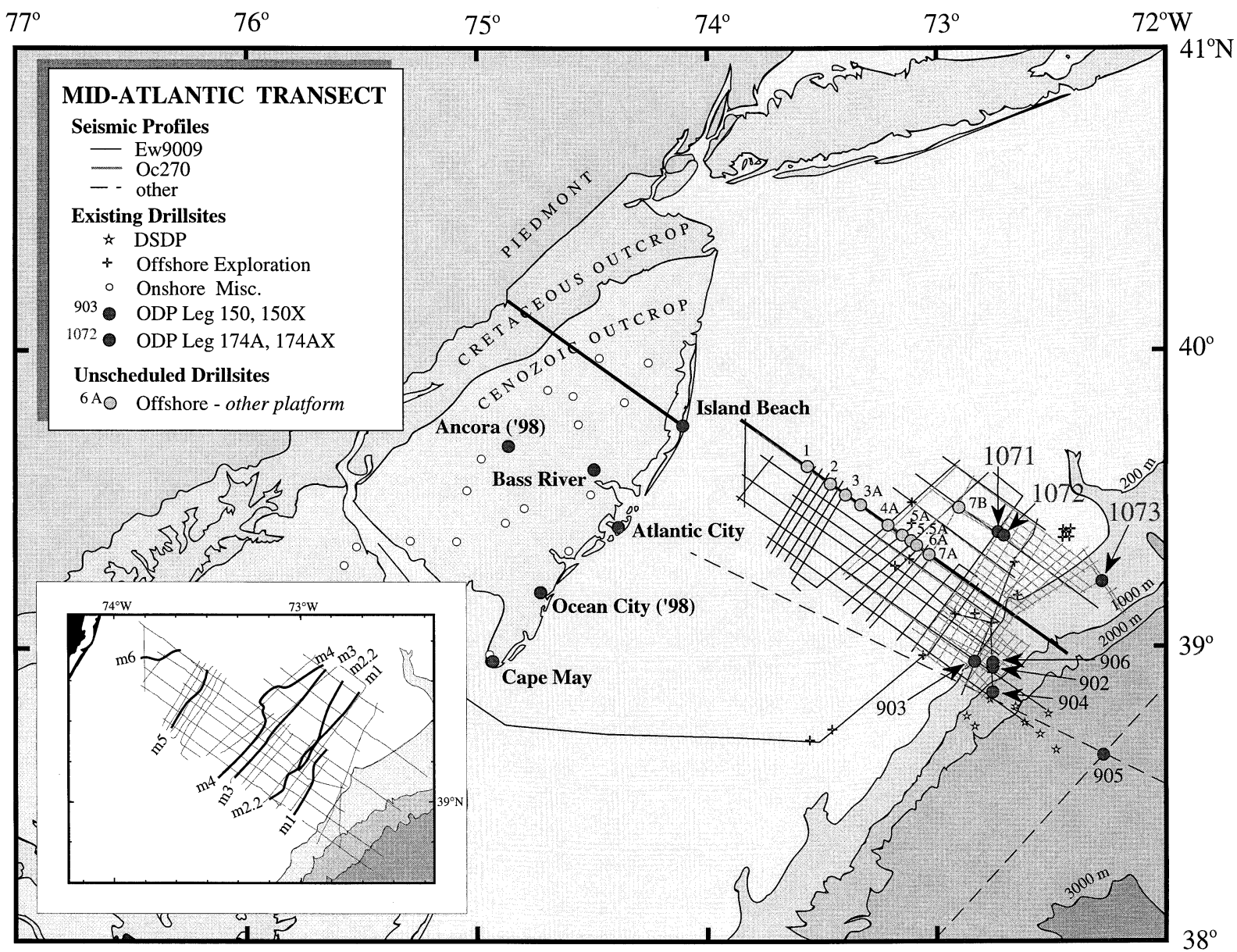

Fig. 1. Location map of the New Jersey margin. The lines show the Ewing 9009 multichannel seismic grid. The heavy lines indicate MCS line 1003 and the geologic section of Olsson et al. (1988), which were used to construct the profile for the reconstructions. Also shown are the existing (dots), and proposed (circles) ODP boreholes, industry wells (plus-signs) on the shelf and slope, and previous DSDP holes on the slope and rise (stars). Sites 1071-1073 were drilled in 1997 during Leg 174A. The inset in the lower left shows the positions of clinoform rollovers along the grid. The $\mathrm{m} 1$ surface shows two rollovers in different parts of the grid. 
1997). Additional drilling on land is designated Leg 174AX. Together, these data make the New Jersey margin one of the best-sampled locations to investigate the interplay of sedimentation, sea level and climate in a siliciclastic setting.

Despite all of these efforts, the water depth and lithofacies of the Miocene sequences remain poorly known. Whether sea-level fall caused subaerial exposure of the tops of the clinoforms, or they remained submerged with the shoreline never reaching the clinoform rollover (i.e., boundary between topset and foreset strata) is a matter of controversy. The correct interpretation has significant implications for how sequence boundaries develop. Most interpretations of this margin simply assume that the shoreline was located near the clinoform rollover. Numerical models of strata on the New Jersey margin (e.g., Lawrence et al., 1990; Schroeder and Greenlee, 1993; Spinelli et al., 1998) similarly assume that the shoreline coincided with the clinoform rollover. The sea-level estimates of Greenlee and Moore (1988) and Greenlee et al. (1992) assume that sea-level falls exposed the shelf and that some of the onlap onto clinoforms was coastal onlap. Indeed, type 1 sequence boundaries, such as those imaged on New Jersey, are generally assumed to expose the entire continental shelf (Posamentier et al., 1988; Van Wagoner et al., 1990). However, this assertion is questionable (Steckler et al., 1993; Fulthorpe and Austin, 1998). Vail et al. (1991) acknowledged that the offlap break at the clinoform rollover and the shoreface are distinct morphologic features. Nonetheless, many workers use the interpretation of coastal onlap onto the clinoform fronts to estimate the amplitude of sea-level cycles. Measurement of the amplitude for sea-level fall and subsequent rise is critically dependent on whether lowstand onlap is truly coastal or deeper marine. Therefore, determination of water depth at the clinoform edge is critical to sequence stratigraphic theory.

Whereas the Oligocene to Recent sequences are characterized by distinct clinoform morphology, the underlying Cretaceous to Eocene strata are flatlying, with little distinctive geometry beneath the continental shelf. This contrasting geometry may be due to many causes (e.g., drainage, aridity, overall climate, shelf wave and current regime, etc.). The Eocene strata are composed predominantly of carbonate, while the younger strata are siliciclastic (Miller et al., 1996). Reconstructions of the margin off southern New Jersey suggest that the Eocene shelf was relatively deep (Steckler et al., 1993). The margin was starved of clastic sediments until the Late Oligocene, when coarse siliciclastic input began (Miller et al., 1997). Increasing sedimentation rates (Poag and Sevon, 1989; Mountain et al., 1994) led to progradation. The change in sediment supply has been attributed to increased continental erosion from tectonic uplift (Poag and Sevon, 1989; Pazzaglia, 1993; Pazzaglia and Brandon, 1994), lowered base level from long-term sea-level fall (Miller et al., 1996) and climate change (Steckler et al., 1995).

Hypotheses for the Tertiary evolution of the New Jersey margin must be tempered by the knowledge that the present geometry of preserved strata differs from its depositional morphology, due to deformation by subsidence, compaction, sediment loading and tectonics. Nor does sequence geometry necessarily provide a good measure of facies and paleobathymetry. One approach to addressing these problems is to use backstripping techniques for reconstruction of past bathymetry and stratigraphy (Steckler et al., 1988, 1993). This paper is part of the ONR STRATAFORM program, designed to understand the formation of strata on margins (Nittrouer and Kravitz, 1995; Austin, 1997), and we use the Ewing 9009 data to develop a more detailed restoration of the Tertiary evolution of the New Jersey margin.

The backstripping approach can be used to remove sediments layer by layer, and thereby reconstruct the morphology of ancient surfaces and the geometry of the underlying strata. In this manner, the past shapes and gradients of the continental shelf, and the shape and height of clinoforms on the New Jersey margin can be estimated. Similarly, the depth of the clinoform rollover and its position relative to the shoreline can be evaluated. Detailed reconstruction of the margin allows us to examine the geometry of the sequences and bounding surfaces as they appeared, rather than as they are preserved. The New Jersey margin developed under the combined influence of fluctuating sea level, changing climate, and variable sediment supply. By reconstructing the past morphology of the margin, we gain insight into how these processes shaped the margin during the Tertiary. 


\section{Database for the New Jersey margin}

The primary data set used to define the sequences on the New Jersey margin for this study is the grid of seismic profiles collected on the R/V Maurice Ewing 9009 cruise during November 1990 (Fig. 1). The 60-fold MCS data were collected with a tuned array of six airguns having a total volume of 1350 cu. in., towed at a depth of $6 \mathrm{~m}$ and recorded using a 120-channel streamer with 12.5-m group spacings and 1-ms sampling rates. This provided a higher-resolution data set than was available in existing academic and industry MCS lines. Interpretation of these data has nearly doubled the number of Oligocene-Miocene sequences that could be identified (compared with previous commercial data; e.g., Greenlee et al., 1992). The system also has enabled the tracing of shelf sequences onto the upper continental slope, where they were sampled by ODP Leg 150 drilling. The clinoform geometry could be better mapped spatially and it shows a generally twodimensional advance of the clinoforms across the shelf (Fig. 1, inset) (Poulsen et al., 1996; Fulthorpe and Austin, 1998; Spinelli et al., 1998). For this study, we have used line 1003 in the center of the grid (Figs. 1 and 2). This line was the original focus of the Mid-Atlantic Transect (MAT) and contained ten of the proposed drill sites. It is also the line that extends closest to shore, decreasing the gap to the wells on land. Unfortunately, the quality of this profile degrades near the shelf edge (Fig. 2), due presumably to gas in the upper several hundred meters beneath the seafloor. Therefore, the reconstructions in the present study extend only to a position $19 \mathrm{~km}$ landward of the present shelf edge.

Age control for the sequence boundaries identified on the seismic section was provided by ties to ODP Leg 150 on the continental slope (Fig. 3). ODP Leg-150 sites were located on lines 1005 and 1027 of the Ewing 9009 seismic grid. Synthetic seismograms have been used to tie the reflections to the boreholes (Lorenzo and Hesselbo, 1996) where they have been dated (Mountain et al., 1994; Mountain et al., 1996b; Miller et al., 1996). These correlations have been traced to line 1003 and the rest of the Ewing 9009 seismic grid. The age control is summarized in Miller et al. (1998).

More sequences were identified on the seismic grid than have been firmly tied to the ODP drill sites on the slope; their ages were interpolated and are approximate (Fig. 4). Most of these sequences are in the younger part of the section. When all of the identified sequences are considered, a shift in the frequency of sequence boundaries is apparent. The older sequences have an average duration of $\sim 1-2$ m.y., and this decreases in the younger sequences to $<0.5 \mathrm{~m}$.y. The switch between these two periods occurs at $\sim 14 \mathrm{Ma}$, coincident with a major shift in $\delta^{18} \mathrm{O}$ towards heavier values and a large increase in Antarctic ice (Miller et al., 1991) (Fig. 3).

Line 1003 was converted to depth using semblance velocities. The accuracy of the conversion was checked by comparing the estimated depths of sequence boundaries to the depths observed on the Shell 632-1 well, which lies over the Great Stone Dome near $\mathrm{km} 173$ on the line. Three sequence boundaries in the lower part of the section that could be positively identified on both the seismic data and well $\operatorname{logs}$ (o1, m5 and $\mathrm{m} 4$ ) agreed to within $12 \mathrm{~m}$. This well also provided lithologic information from the middle of the continental shelf, complementing the data from land and from the upper slope. Sixteen surfaces from the Middle Miocene to the K/T boundary on line 1003 were digitized and the depths to each surface were interpolated along track at a 250-m spacing (Figs. 2 and 4).

For the part of the profile on land (Fig. 4), we used the dip section of Olsson et al. (1988) from Trenton to Island Beach. Depths at the Island Beach site were revised to agree with the new Island Beach borehole drilled as part of the New Jersey Coastal Plain Drilling Project (Miller et al., 1994). The basal unconformity for the Miocene sequences in Island Beach shows Kw1a overlying Upper Oligocene O6 sediments (Fig. 4). The absence of $\mathrm{Kw} 0$ in Island Beach is in agreement with the coalescence of surfaces $\mathrm{m} 6$ and $\mathrm{m} 5.6$ that bound this interval at the landward end of line 1003. The youngest preserved Miocene unit at Island Beach is the Wildwood Member of the Kirkwood Formation, interpreted as Kw2a by Miller et al. (1994). The equivalent interval, between surfaces $\mathrm{m} 5$ and $\mathrm{m} 5.2$, pinches out on line 1003. Therefore, we have reinterpreted this interval as $\mathrm{Kw} 2 \mathrm{~b}$, correlating to the interval between $\mathrm{m} 4$ and m5 instead; this may be true because the differentiation of $\mathrm{Kw} 2 \mathrm{a}$ from $\mathrm{Kw} 2 \mathrm{~b}$ at Island Beach is based 

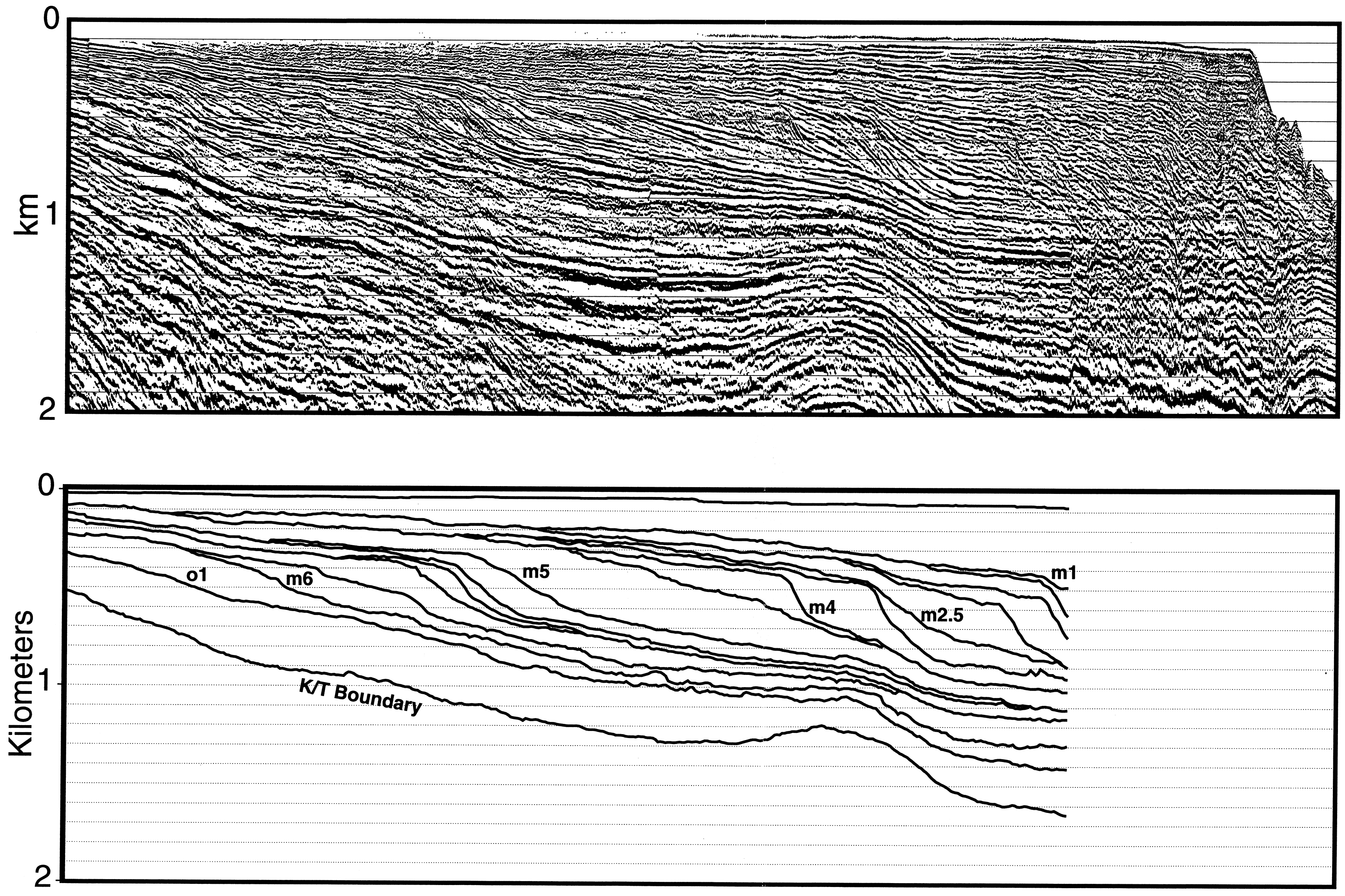

Fig. 2. Highly compressed depth-converted image of Ew9009 line 1003 (above) and line drawing of the interpreted surfaces (below). The outer part of line 1003 was not interpreted due to the poor quality resulting from gas in the sediments. Note the well-developed progra
travel time. The arched sediments in the middle of the profile below $1.25 \mathrm{~s}$ overlie the Great Stone Dome. 


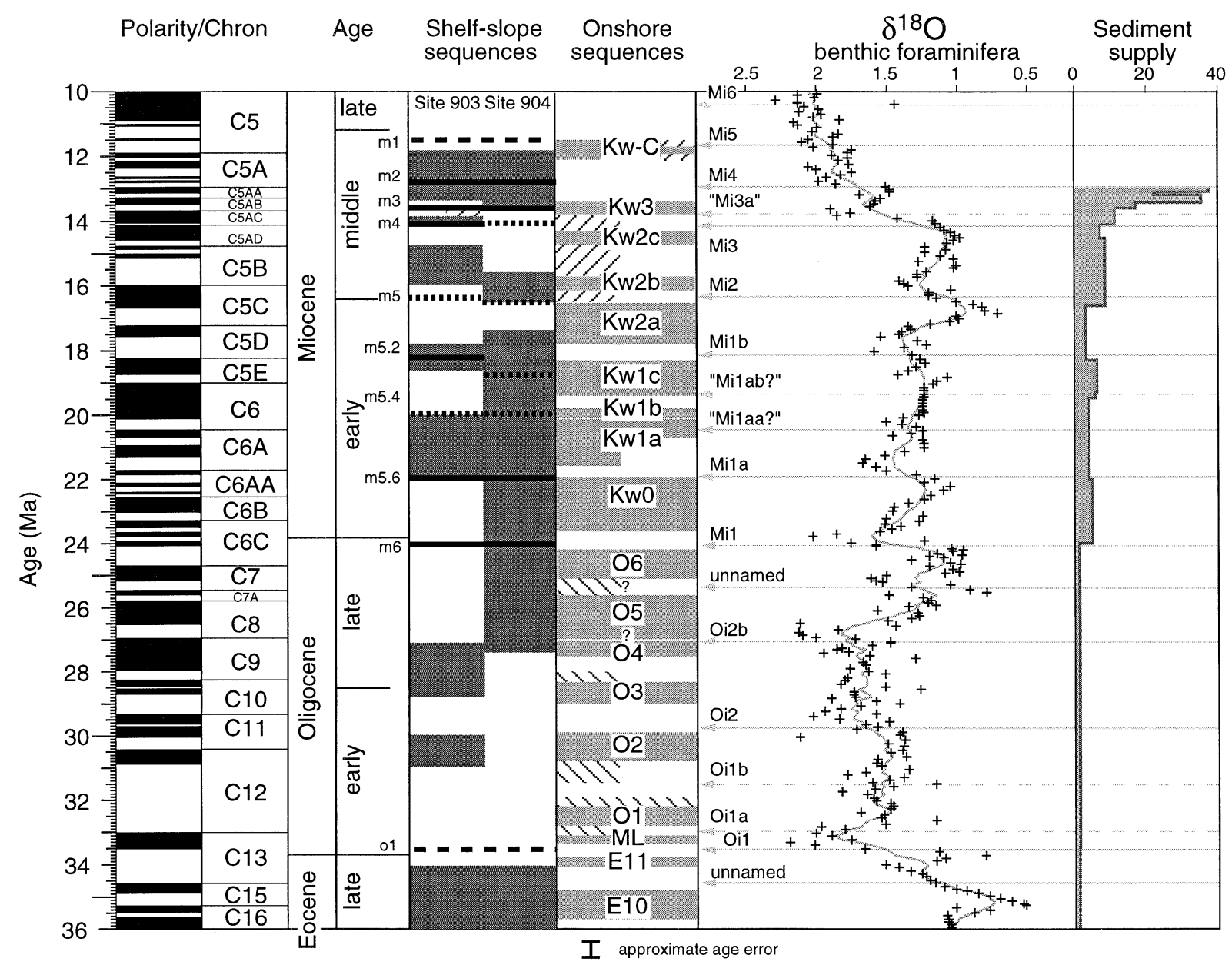

Fig. 3. Correlation of Oligocene to Middle Miocene surfaces on the New Jersey margin with a summary of drilled offshore and onshore sequences and a stacked benthic foraminiferal $\delta^{18} \mathrm{O}$ record. $o 1$ to $\mathrm{ml}$ are surfaces mapped on the shelf and correlated to the ODP Leg 150 boreholes. Solid and dashed lines indicate the age estimates at sites 903 and 904. Sediments in offshore and onshore wells are indicated by dark boxes; white areas in between are hiatuses. The $\delta^{18} \mathrm{O}$ is a stacked record of Cibicidoides spp. from several sites that has been smoothed to remove all periods shorter than $\sim 1$ m.y. Oil to Mi6 are $\delta^{18} \mathrm{O}$ maxima; light lines indicate inflections in the $\delta^{18} \mathrm{O}$ records. Time scale is that of Berggren et al. (1995). The right-hand side shows the increase in sediment supply through time that is recorded by the cross-section (Fig. 4).

entirely on the presence of Rhaphinodiscus marylandicus, a marker for lower-mid East Coast Diatom Zone 2 ( $\sim$ Kw2a) (Miller et al., 1994). We correlate the intervening sequence boundaries, found at the top and bottom of the Shiloh Member in Island Beach, to m5.2 and m5.4 on line 1003. Because only undifferentiated Miocene Kirkwood Formation is shown on the published land section (Olsson et al., 1988), we interpolated the position of these two surfaces within the Coastal Plain. The uncertainties in the positions of the sequence boundaries in the Coastal Plain and in the correlations amount to a few tens of meters. This leads to uncertainties much smaller than those in the Early Miocene reconstructions.

\section{Continental-margin reconstruction}

We have used a modification of the backstripping technique to reconstruct the geometry of the continental margin through time. Backstripping is generally used to estimate tectonic subsidence by account- 

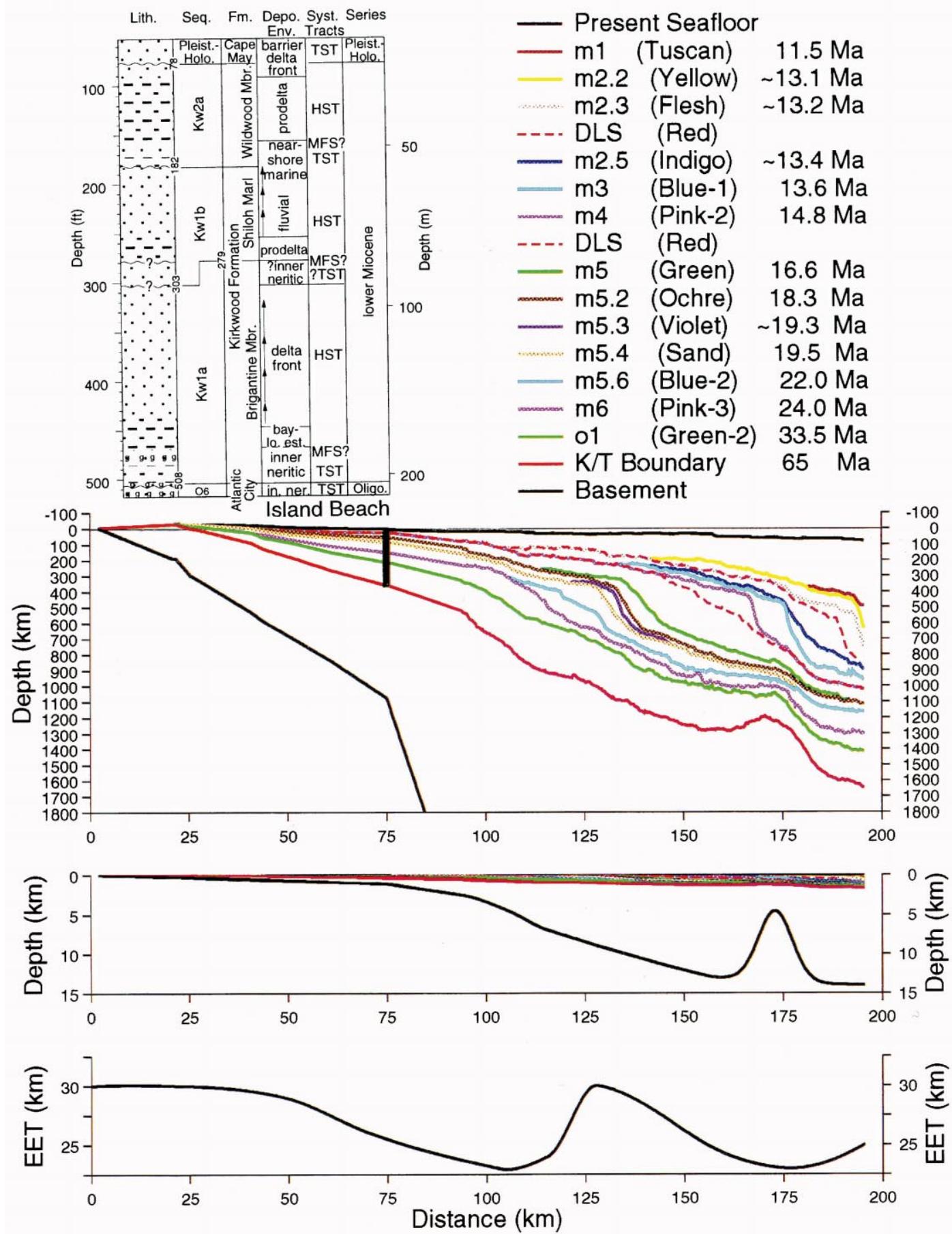

Fig. 4. Cross-section used in the reconstructions. The top left shows a summary of the recovered sediments and their interpretation for the Island Beach borehole located at the shoreline. The top right shows the surface nomenclature and ages with the color scheme used. Below are two line drawings of the cross-section of the New Jersey margin used for the reconstructions. They are shown with a vertical exaggeration of $40: 1$ and with a vertical exaggeration of $2: 1$ in order to present both the details of the Tertiary surfaces digitized and the depth to basement. The basement high is the Lower Cretaceous intrusion of the Great Stone Dome. Clinoform shapes of the Miocene reflectors are clearly seen. Compactional drape over the Great Stone Dome can also be seen in reflector geometry. The bottom shows the distribution of flexural rigidity used for the backstripping across the margin. 
ing for and removing the effects of other causes of subsidence, such as loading due to the sedimentary column. However, where the tectonic subsidence can be estimated, as is the case for New Jersey, the backstripping approach can instead be used to calculate the paleobathymetry and reconstruct the stratigraphy through time (Steckler et al., 1988). This is similar to the backtracking of sediments on oceanic crust in the deep sea (Berger and Winterer, 1971).

The process of reconstructing the development of a continental margin consists of a number steps (Fig. 5) (Steckler et al., 1993). Essentially, we accounted for the processes that cause subsidence or deformation of the stratigraphic section and sequentially removed them. First, we removed all of the sediments above the horizon of interest. We then calculated the weight of sediment corresponding to the removed layers, and flexurally unloaded the remaining layers. The value for flexural rigidity at continental margins has been controversial (Watts, 1988; Fowler and McKenzie, 1989; Karner, 1991; Kooi et al., 1992). To estimate its value at the New Jersey margin, we used a new parameterization that accounted for the influence of large variations in sediment and crustal thickness at the margin, as well as other factors (Lavier and Steckler, 1997). This model predicts that the Miocene elastic thickness at the New Jersey margin varies between 23 and $30 \mathrm{~km}$ (Fig. 4). We used this variable elastic thickness to compute the isostatic rebound of the underlying layers.

Next, we corrected the sedimentary layers below the horizon of interest for the compaction that occurred since the time of the reconstruction. For decompaction, we used an exponential decrease in porosity with depth for each lithology (Sclater and Christie, 1980). We assigned each layer (down to basement) a mixture of sediment types based on results from the wells drilled in the region during ODP Legs 150 and $150 \mathrm{X}$ and during hydrocarbon exploration. The layers were then decompacted to their earlier porosities and their depths adjusted.

Then, the thermal subsidence that occurred since the deposition was removed. In an old margin such as the U.S. Atlantic margin, the observed tectonic subsidence during the Tertiary follows a smooth exponential whose shape is insensitive to the details of the rifting history, including the extent of volcanic construction. The sedimentary and lithospheric
Original Profile

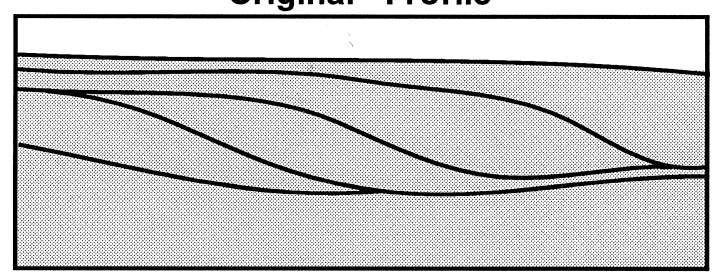

Remove Layer

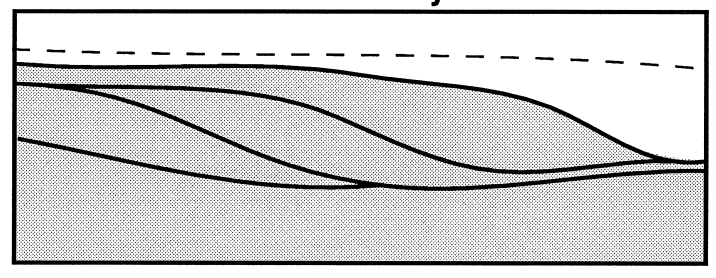

Flexurally Unload

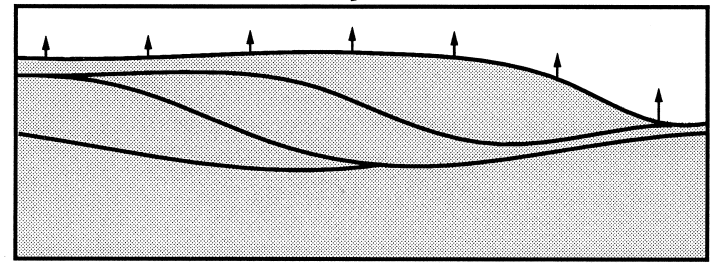

Decompact

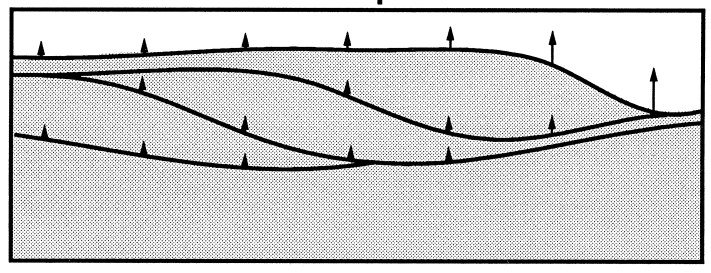

Remove Subsidence

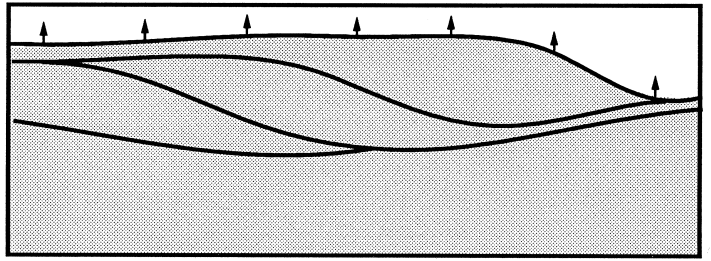

Adjust Sea Level

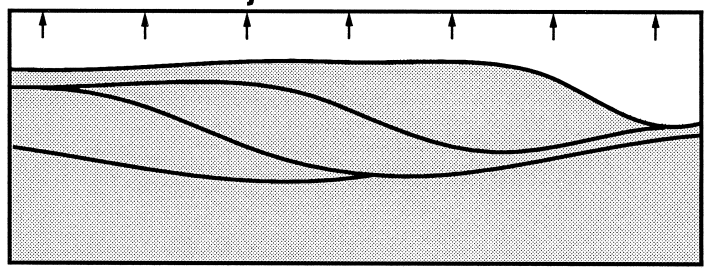

Fig. 5. Cartoon illustrating the steps used in reconstructing the stratigraphy and paleobathymetry of the New Jersey continental margin. See text for details. 
structure has been determined by seismic reflection, seismic refraction and gravity data (Sheridan et al., 1988; Grow et al., 1988; Diebold et al., 1988; Holbrook and Keleman, 1993; Klitgord et al., 1994). Based on these data and deep borehole data, the overall tectonic subsidence of this margin has been estimated by several authors (Watts and Thorne, 1984; Steckler et al., 1988; Keen and Beaumont, 1990). We calculated the thermal subsidence for the interval between the Oligocene and the present, using a two-dimensional thermal model for the New Jersey margin similar to that of Steckler et al. (1988).

Finally, the profile was adjusted for the sea-level change since the time of the reconstruction. This consisted of changing both the reference level for the profile, and of loading/unloading by the thickness of water. The water loading was removed using the same flexural routines as for removal of the sediment load. We used the long-term estimates of Kominz (1984) for the sea-level history. This curve does not include high-frequency glacioeustatic fluctuation. A different sea-level curve would have produced primarily vertical shifts of the paleodepths for the entire reconstruction. The final result is a reconstruction of the paleobathymetry and the geometry of underlying horizons across the continental margin at the sequential time intervals of the reconstruction.

Uncertainties in the reconstructions were assessed by varying the flexure and compaction parameters used for the reconstruction. Compaction errors arise from uncertainties in the lithology and the compaction coefficients of those lithologies. The errors scale with the thicknesses of sediments removed. Thus, the largest errors occur at the seaward end of the profile and they decrease landward. Uncertainties of $25 \%$ in the compaction parameters could produce errors of up to $65 \mathrm{~m}$ for the 1300 -m-thick section on the seaward part of the line. The clinoform edges vary from 300 to $500 \mathrm{~m}$ below the seafloor; errors for these depths are only 5-15 m. Experiments varying the lithologies of the layers fell within these ranges. Uncertainties from varying the flexural rigidity distribution are up to $\sim 100 \mathrm{~m}$ for the deepest reflectors on the seaward part of the line. They decrease for younger surfaces and taper to zero at the landward end of the profile. Because the older, deeper surfaces are also associated with more landward rollovers, the uncertainties for the clinoform rollover depths remain fairly constant at $\sim 30 \mathrm{~m}$. Flexural unloading produces a smooth isostatic response; thus it primarily affects the clinoform depth. The compaction depends upon the local overburden removed; thus it influences the height of the reconstructed clinoforms.

\section{Results}

We reconstructed a series of fifteen time intervals from the Oligocene to the Middle Miocene. The reconstructions extend from the Fall Line (the landward pinchout of the Coastal Plain), to approximately $19 \mathrm{~km}$ west of the present shelf edge. Farther seaward on line 1003, the sequences are not clearly imaged. In order to account for the loading effects from changes in sequence thicknesses beyond the profile, we approximated the stratigraphy farther seaward. We extended horizons to the position of the shelf edge, then linearly tapered the thicknesses to zero at the position of the Eocene outcrop on the middle continental slope. For the continental rise, we linearly increased the sediment thickness to the values at the shelf edge. The effect of the taper is to shallow the depths by decreasing the sediment load in the continental rise. The amount is $30-100 \mathrm{~m}$ at the seaward end of the profile and decreases rapidly landward. Errors due to inaccuracies in this approximation would only be a fraction of the correction and thus do not affect the conclusions of this study.

Reconstructions for eight of the time intervals (Fig. 6) illustrate the progradation of the OligoMiocene sequences over the initial Eocene shelf surface. Several overall features are apparent. At the landward end, truncation of the Cretaceous section is evident. Previously the Cretaceous extended farther landward. The effect of restoring this eroded section would be to slightly deepen the landward part of the reconstruction. At the seaward end of the profiles, the Great Stone Dome, an Early Cretaceous intrusion, is centered near kilometer 175 (Fig. 4). Compactional drape of the horizons is evident in the profile and present depth section (Figs. 2 and 4). This stratal distortion is subdued to absent in the reconstructioned paleobathymetry, indicating the success of the compaction estimates.

The slight dip in the bathymetry at the present shoreline $(\mathrm{km} 75)$ for the first few reconstructions 
is an artifact of patching together the two offset sections of the profile (Fig. 1). The Lower Miocene and Oligocene strata are thicker on the coastal-plain section than on line 1003. This is due to an overall increase in thickness along-strike to the south, and the geometry of the initial Oligocene progradation, which apparently progressed north to south (Pekar and Miller, 1996).

The first reconstruction (Fig. 6A) is for the o1 surface, equivalent to $\delta^{18} \mathrm{O}$-event Oi1, the glacioeustatic event near the base of the Oligocene (Fig. 3; Miller et al., 1996). Overall, the restoration shows a relatively flat, seaward-dipping ramp. The predicted paleo-depth for the Island Beach borehole is $96 \mathrm{~m}$, in agreement with the paleontological estimate of 80 $100 \mathrm{~m}$ (Pekar and Miller, 1996). The shoreline was considerably landward of its present location. The gradient of the shelf at that time was about $0.1-0.2^{\circ}$, or $1: 300$ to $1: 500$. This is three to five times steeper than at present.

The next reconstruction (Fig. 6B), for m6, shows a clear sigmoid shape on the profile. Several similar, small clinoforms are also present within the Oligocene section between o1 and m6 surfaces (S. Pekar, pers. commun., 1998). The height of the m6 clinoform, and the similar one for the next time slice, m5.6, are 22 and $46 \mathrm{~m}$, respectively. The rollovers of these clinoforms are reconstructed at water depths of 105-127 m, although there is some distortion in this part of the profile. It is possible that these clinoforms correspond to shorefaces from the maximum lowstand of sea level, although we consider it unlikely. The upper part of the m6 sequence in the Island Beach borehole, at the present shoreline position, has been removed by erosion. However, the preserved transgressive systems tract in the borehole, nearly $40 \mathrm{~km}$ landward of the $\mathrm{m} 6$ clinoform imaged on line 1003, is composed of glauconitic inner neritic sands. Thus, for the $\mathrm{m} 6$ clinoform to be a preserved shoreface, the sea-level fall would have had to shift the shoreline from a position considerably landward of the Island Beach borehole to the position of the preserved clinoform.

The next two reconstructions (Fig. 6C,D), for $\mathrm{m} 5.4$ and $\mathrm{m} 5$, show the continued growth of the clinoforms and sediment progradation across the older ramp margin. The tops of these and the intervening clinoforms are reconstructed as water depths of 60-
$80 \mathrm{~m}$. However, the heights of these clinoforms are greater, $116-131 \mathrm{~m}$. The dimensions of these and subsequent clinoforms are clearly much larger than shorefaces. Rather, they suggest a new and flatter continental shelf that was built over the older ramp margin. The clinoform front would then correspond to the position of the new shelf edge as the modern continental shelf developed. Indeed, the gradients across the top of these and the other clinoforms in the reconstructions are similar to the gradient of the present continental shelf.

During the following sequence, m4, (Fig. 6E), the margin prograded rapidly. The rollover position advanced by $33 \mathrm{~km}$. A prominent downlap surface (DLS) within this sequence is visible on the seismic line (Fig. 2). The clinoform that developed was higher and steeper than its predecessors. It was over $250 \mathrm{~m}$ high, with a dip $>2.5^{\circ}$ on its front slope. The rollover of the clinoform, however, remained at a similar depth, $90 \mathrm{~m}$. The strata beneath the clinoform were distorted into a syncline as a result of compaction (Reynolds et al., 1991), which is particularly evident in this time interval. Subsequent progradation depressed the strata seaward of the syncline, straightening the strata and rolling the syncline forward. This rolling syncline effect is a transient that is present in all of the reconstructions.

Following the major seaward shift associated with $\mathrm{m} 4$, the margin continued to prograde (Fig. 6F). The clinoform remained high and steep. Then, for $\mathrm{m} 2.5$ reconstruction, the gradient of the clinoform front decreased (Fig. 6G). The rollover remained in the same location and did not migrate, whereas most of the sediment was deposited seaward of the clinoform rollover. Poulsen et al. (1996) mapped the spatial configuration of the clinoforms in this part of the Ewing 9009 survey. Although both earlier and later sequences exhibit a linear clinoform front (see Fig. 1), this surface, $\mathrm{m} 2.5$, exhibits a local threedimensional configuration of the clinoform near line 1003. We are not certain whether this could fully account for the observed clinoform shape.

By the time of the next sequence, m2.3 (Fig. $6 \mathrm{H}$ ), the clinoform front resumed its earlier shape. This sequence was again one in which the progradation was large and a prominent DLS is observed. The progradation continued across the margin, but the clinoforms are cut off by the end of the profile. Ex- 

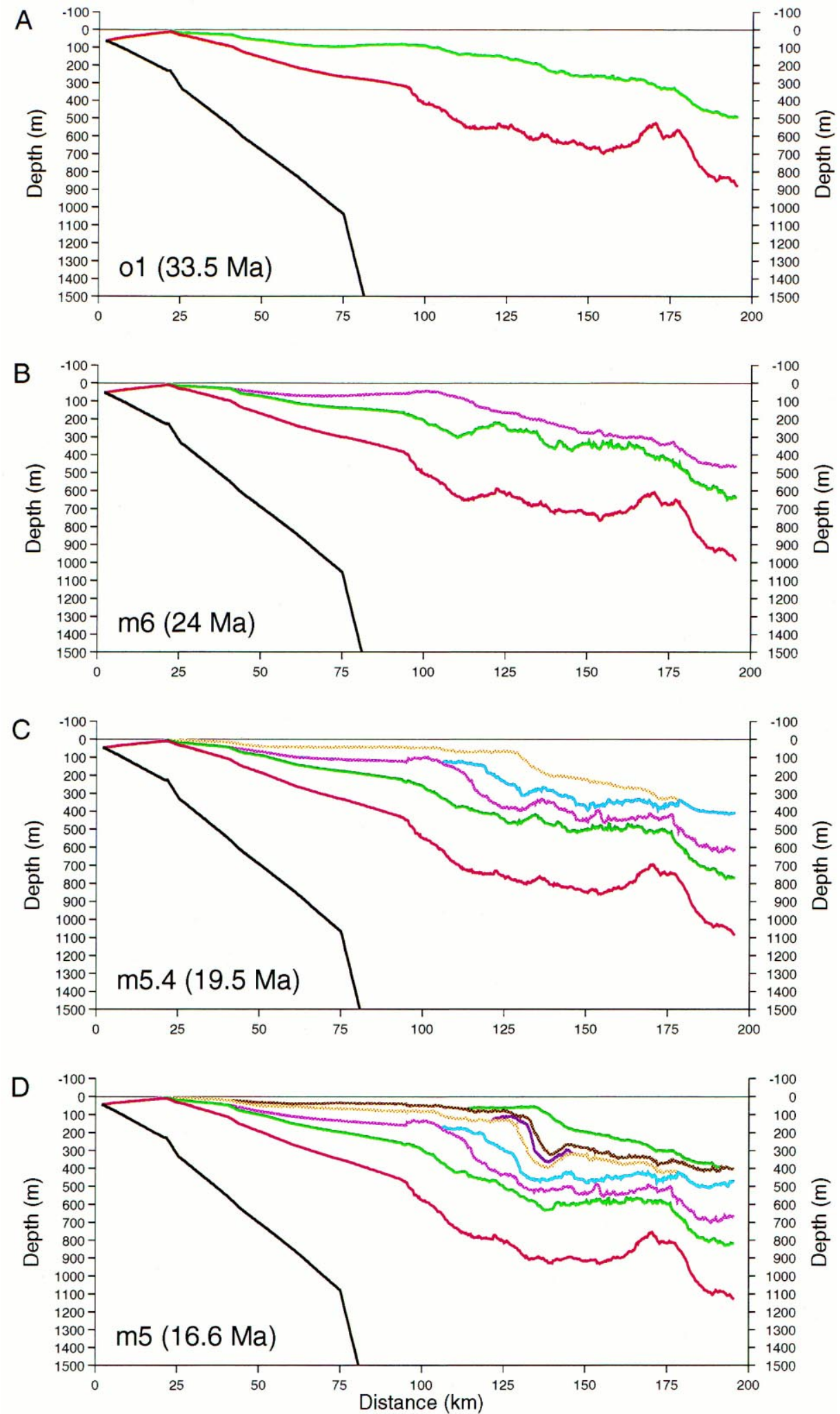

Fig. 6. For description see p. 414. 

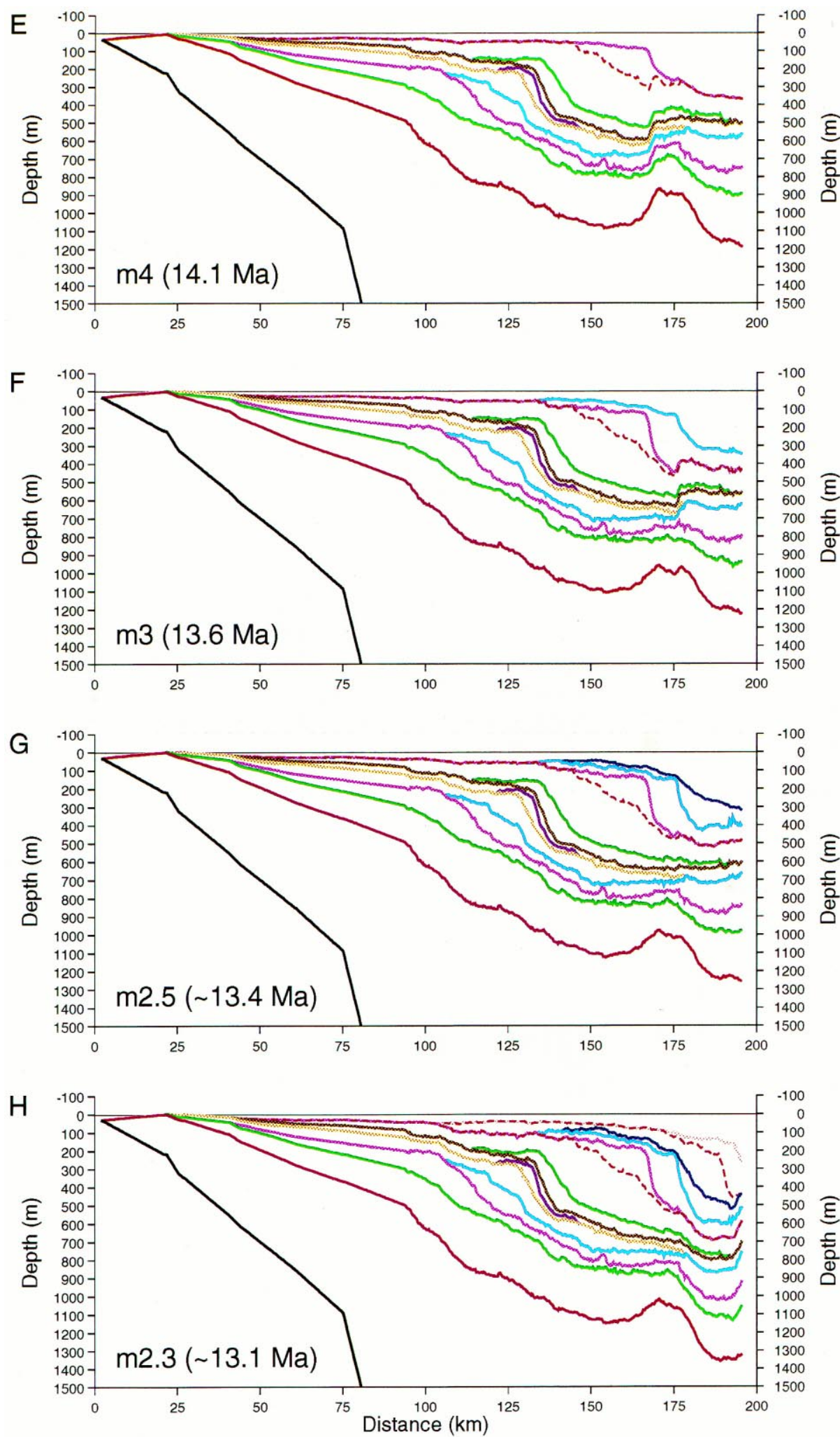

Fig. 6 (continued). 
amination of the grid of seismic lines shows that the pattern of sediment progradation across the old ramp margin continued, with occasional deviations from linearity (Fig. 1). At the present time, the progradation has filled all of the available accommodation above the old Eocene ramp margin. The deep shelf edge of this margin lies beneath the present continental slope. Eocene strata still crop out on the lower continental slope. As the space on the shelf filled, an increasing proportion of the sediment supply bypassed the shelf to create the present large depocenter on the continental rise. Mountain and Tucholke (1985) concluded that a considerable amount of Neogene sediment on the continental rise began to be deposited by $12 \mathrm{Ma}$.

\section{Discussion}

On the largest scale, the continental shelf reconstructions document a transformation from a ramp (Fig. 6A), with a shelf edge of at least $500 \mathrm{~m}$ water depth (Farre, 1985; Steckler et al., 1988, 1993), to the present, flatter shelf with a well-defined shelf break at $\sim 130 \mathrm{~m}$ water depth. This transformation was caused by the progradation of siliciclastic sediments in the form of clinoforms across the shelf. The increased sediment supply represented by these clinoforms filled the available accommodation space. In the warm climate of the early Eocene, sedimentation at the New Jersey margin was predominantly pelagic carbonate and the terrigenous sediment flux was low (Miller et al., 1997). Backstripping and paleoecological analyses (Steckler et al., 1988, 1996a; Katz and Miller, 1996) show deepening of the shelf, as the sedimentation rate did not keep up with the modest thermal subsidence. As the climate cooled through the Eocene, the region of the modern coastal plain witnessed a changeover to terrigenous sedimentation. As a response to a major phase of Antarctic glaciation in the earliest Oligocene (Oi1 event), the New Jersey climate cooled (Owens et al., 1988), and the carbonate sedimentation shut down in an episode termed the 'siliciclastic switch' (Miller et al., 1996).

Starting in the Oligocene and accelerating during the Miocene, an increased terrigenous sediment flux led to the progradation across the continental shelf. Sediment starvation seen in the onshore wells at the 'siliciclastic switch' was followed by shallowing as clastic sediment deposition increased. Using the line-1003 profile, we estimated sediment supply both as the mass of sediment between surfaces and the decompacted sediment volume. The sediment supply that is recorded on the profile (Fig. 3) increased from $1.5 \mathrm{~m}^{2} / \mathrm{y}$ in the Paleogene sequences to $\sim 5$ $\mathrm{m}^{2} / \mathrm{y}$ in the Lower Miocene (m6-m5). The sediment supply increased rapidly from 8 to $17 \mathrm{~m}^{2} / \mathrm{y}$ in the next set of sequences $(\mathrm{m} 4-\mathrm{m} 2.5)$ and then jumped to $\sim 33 \mathrm{~m}^{2} / \mathrm{y}$ for the youngest sequences reconstructed (m2.3-m2.2). This dramatic increase in sediment supply (occurring soon after $\mathrm{m} 4$ time) coincides with the major Middle Miocene $\delta^{18} \mathrm{O}$ increase represented by Mi3 and Mi4 (Fig. 3). These sediment supply increases are minimum estimates, because an increasing proportion of sediment would have been deposited seaward of the profile end. The progradation rate also increased from $\sim 3 \mathrm{~km} / \mathrm{Ma}$ in the Early Miocene $(\mathrm{m} 6-\mathrm{m} 5)$ to $\sim 16 \mathrm{~km} / \mathrm{Ma}$ in the Middle Miocene (m4-m2.2). The increased sediment supply and progradation rate improves the ability to discern smaller-scale sequences beneath the shelf. While the older sequence boundaries average $\sim 1.5$ m.y. apart, the average time interval between mapped surfaces in the younger part of the section is only a few hundred thousand years.

The times of changes in the sediment supply also correspond to a larger-scale cyclicity in the progradation. This cyclicity is apparent in the positions of the clinoform rollovers mapped by Greenlee and Moore (1988) and in the reconstructions of Steckler et al. (1993) farther south. Miller and Mountain (1994) showed three Miocene suites of cycles that they designate as lower, middle and upper Neogene in age. The packages are separated by seaward shifts in the rollovers of 33 and $18 \mathrm{~km}$ and the development of prominent downlap surfaces.

Fig. 6 (see pp. 412, 413). Series of reconstructions showing the stratigraphy and bathymetry of the New Jersey margin through time. The figure shows selected time slices from the Oligocene to the Middle Miocene as noted in the lower left of each reconstruction. Color scheme for the surfaces is indicated in Fig. 4. 


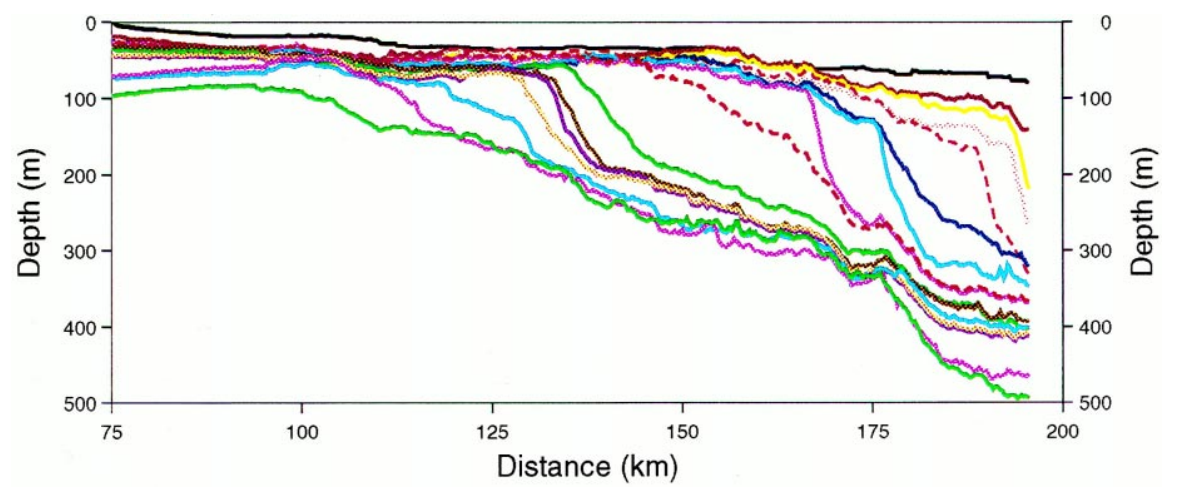

Fig. 7. Plot of reconstructed paleobathymetry for all of the time slices from the present shoreline to the seaward end of the reconstructions. Present bathymetry is shown at top.

Sediment supply changes are also apparent on the upper continental slope. A one-dimensional reconstruction of the Leg 150 boreholes (Steckler et al., 1996a) shows deepening of the paleowater depths until 15-16 Ma (m5-m4 interval), followed by shallowing. Katz and Miller (1996) document a dramatic increase in terrigenous sediment input and transported shallow benthic foraminifers to the continental slope. This started at $\sim 13.5 \mathrm{Ma}(\mathrm{m} 3)$, coeval with the increase in preserved sediment volume on the profile. The first turbidite fill in submarine canyons is only slightly younger than $\mathrm{m} 3(\sim 13.4-13.0 \mathrm{Ma})$ (Mountain et al., 1996a). These observations indicate sediment spillover as the clinoforms progressed across the shelf.

As the sediments prograded, the clinoform heights increased, as shown in a close-up of the stacked series of bathymetric reconstructions (Fig. 7). While the oldest clinoforms in the reconstructions were only 22-46 m high, younger clinoforms were 175$257 \mathrm{~m}$ in amplitude. This is a natural consequence of the outbuilding of the sedimentary deposits across a seaward-dipping ramp. The tops of the clinoforms were at about $60-130 \mathrm{~m}$ water depth, similar to present-day shelf-edges and subaqueous deltas (Kuehl et al., 1986; Kuehl et al., 1989; Wright et al., 1990; Nittrouer and Kuehl, 1995; Nittrouer et al., 1996). The bases of the clinoforms were the sloping Eocene ramp. Thus, the height of the clinoforms is strongly correlated with the amount of progradation $\left(r^{2}=0.82\right)$. Sediments transported seaward of the clinoform front help to raise the level of the ramp, limiting the height of the clinoforms. For most of the sequences, these deposits significantly raise the ramp only for the first $10-25 \mathrm{~km}$ at the toe of the clinoform.

The steepness of the front face of the clinoforms increases with their height. The dip of the upper slope of the clinoform fronts increase from $\sim 1^{\circ}$ to $\sim 2.7^{\circ}$ as the sediments prograde. Neglecting $\mathrm{m} 2.5$, when the clinoform may have been oblique to the seismic profile, the correlation coefficient between the height and dip angle is $r^{2}=0.79$. We estimate the uncertainty on the dip of the reconstructed clinoforms as $\sim 1 / 3^{\circ}$. Numerical experiments on the progradation of clinoforms predict that the dip angle should increase with clinoform height (Ross et al., 1994; Pirmez et al., 1998). This is because a steeper angle is required to transport the greater amount of sediment required to prograde a higher clinoform.

The reconstructions all show clinoform rollovers at water depths $>60 \mathrm{~m}$. We suggest that these clinoforms represent the progradation of a new continental shelf on top of the older ramp. The clinoform breaks were the shelf edges of this new shelf. The morphology of the clinoforms, with a gently dipping topset and steep foreset is similar to modern clastic continental shelves. This new shallower continental shelf fills in the available accommodation above the carbonate ramp that developed during the warm, early Tertiary 'greenhouse' climate. The switch to predominantly terrigenous sedimentation, which eventually built the new shelf, corresponds with earliest Oligocene glaciation and the progressive development of the 'icehouse' climate (Miller et al., 1991). 
Previous studies (Poag and Sevon, 1989; Pazzaglia, 1993; Pazzaglia and Brandon, 1994) have noted the large Miocene sediment flux in this area and favored a tectonic rather than climatic explanation for the increased flux. We note that a major phase of Antarctic ice development in the earliest Oligocene (Miller et al., 1991) correlates with a cooling at the New Jersey margin (Owens et al., 1988), which resulted in the shutdown of the pelagic carbonate sedimentation (Miller et al., 1996). The margin was starved until about $27 \mathrm{Ma}$, when coarse siliciclastic input began (Miller et al., 1997). Accumulation rates increased further in the Middle Miocene (Poag and Sevon, 1989; Mountain et al., 1994), about the time the permanent Antarctic ice sheet developed (Shackleton and Kennett, 1975; Miller et al., 1991). The latter climatic event may have resulted in the increased sediment supply recorded on line 1003, as well as changes in the tempo of glacioeustatic change. Thus, we conclude that climate had a major influence of sediment flux and sequence development on the New Jersey margin.

We performed reconstructions on the mapped sequence boundaries; the results, therefore, represent water depths at various times. It is likely that transgressive erosion has cut into the sequence boundary, yielding an overestimate of depth. We consider this likely on the more landward part of the topset surfaces, but not a major problem at the rollover. Oxygen isotopic studies suggest that glacioeustatic sea-level falls in the Miocene were about 30-50 m in amplitude or perhaps slightly more (Miller et al., 1991). Water depths for the lower Miocene sediments (preserved in the Island Beach well) reached 10-20 m during the maximum flooding. Depths shallowed to nonmarine in the strata immediately below the sequence boundary. Even if the sequence boundaries formed early in the sea-level fall, the shoreline

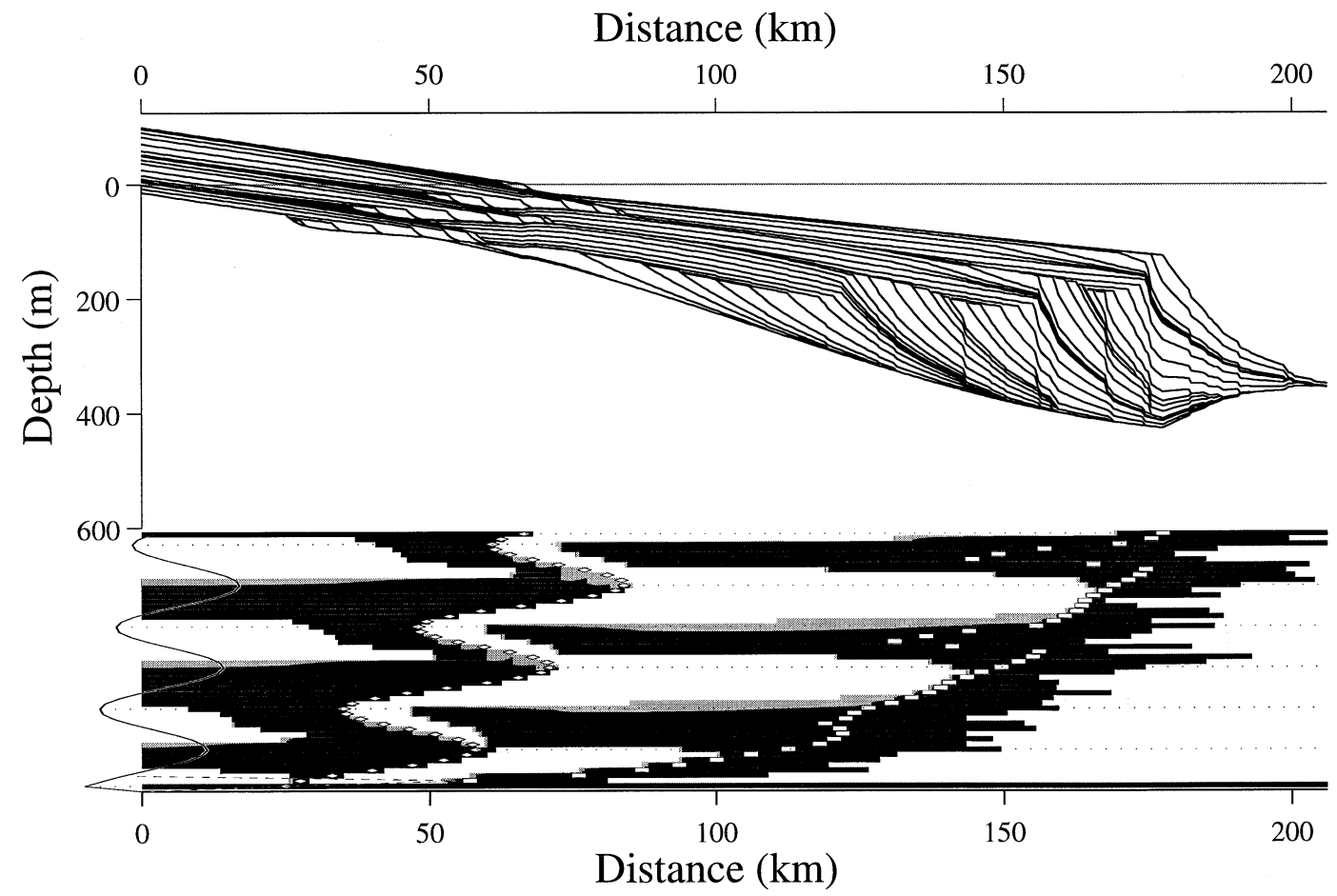

Fig. 8. Simulation of continental-margin stratigraphy showing an example of progradation of several sequences across a pre-existing ramp. The model is driven with a falling sea level combined with a 30-m-amplitude sinusoidal variation. Timelines are drawn every 100,000 years. The shoreline positions are located between 30 and $80 \mathrm{~km}$. The bottom shows a time stratigraphic diagram in which preserved sediments are black, sediments that were deposited and subsequently eroded are gray, and non-depositional hiatuses are white. The diamonds and rectangles indicate the positions of the shoreline and clinoform rollover, respectively. The applied sea-level curve is shown at the left. 
would not reach the clinoform rollover. Sea-level falls of at least $90-120 \mathrm{~m}$ would be required to expose the shelf edges at water depths of $80-100$ $\mathrm{m}$. In order for the onlap over the clinoform front to be coastal, the sea-level falls would have been significantly greater.

We do not consider it necessary for a sea-level fall to expose the entire shelf (i.e., to the shelf edge) in order to create a type 1 sequence boundary. During a sea-level fall, erosion of the shelf and transport of sediments over the shelf break can occur without the shoreline reaching the shelf edge. Fig. 8 shows a numerical simulation (Steckler et al., 1996b) of the progradation across a previous ramp margin modulated by a $30-\mathrm{m}$ sea-level cycle. The simulation shows an increase in clinoform amplitude during progradation, similar to the results from the New Jersey margin. The chronostratigraphic diagram indicates that, during the sea-level falls, the shallowing of the shelf creates a marine surface of regressive erosion (Nummedal et al., 1993). Corresponding with this hiatus, the sediments from land and those eroded from the shelf are transported past the shelf edge. We consider this to be the case on the New Jersey margin. Estimates for the amount of sealevel change based on the assumption that the onlap over the clinoform front is coastal (e.g., Moore et al., 1987; Greenlee et al., 1988), must be considered unreliable.

\section{Conclusions}

We have reconstructed the Eocene to Middle Miocene paleobathymetry and stratigraphy of the New Jersey margin by backstripping. The reconstructions reveal details of the change in margin morphology from a carbonate ramp in the Eocene to a flatter shelf-break margin at present. The ramp margin dipped seaward at $\sim 0.1-2^{\circ}$, three to five times the dip of the present shelf. The Miocene saw a 20-fold increase in the terrigenous sediment supply, which caused the progradation of prominent clinoforms across the margin. We link the increase in sediment flux to global climatic change, rather than local tectonics. The sediments prograded across the margin building clinoforms, punctuated by sea-level fluctuations, and creating a new shallower, flatter shelf on top of the earlier ramp. The clinoform surfaces are bundled into three large-scale cycles, each of which includes several sequences, and indicates a larger-scale depositional pattern on the New Jersey margin. The steepness and height of the clinoforms increased as they prograded onto the deeper parts of the ramp. This is primarily due to the increased sediment supply from the Eocene to Middle Miocene, and the seaward-dipping ramp morphology of the earlier shelf.

The clinoform rollovers on the New Jersey margin represent the edge of the new continental shelf. The shelf breaks average about 100-m water depth. Sea-level fall was probably insufficient to drive the shoreline past the shelf break. Exposure of the entire shelf and shelf edge are not required to generate type 1 sequence boundaries. Modeling suggests that lowering of sea level and reduction of shelf water depths are sufficient to cause bypassing and erosion of the shelf, and to supply the sediment for lowstand fans. Thus, measurements of sea-level amplitude derived from presumed coastal onlap over the clinoforms are not reliable.

\section{Acknowledgements}

We thank our fellow members of the STRATAFORM Program for valuable discussions and suggestions. We thank Jamie Austin, Chuck Nittrouer, Dan Orange and Bob Sheridan for constructive reviews, and Luc Lavier for assistance with flexural calculations. This work was supported by ONR grants N00014-95-1-0076 and N0014-95-1-0200, and NSF grants EAR92-18210, EAR94-17108, and EAR9505957. Lamont-Doherty Earth Observatory contribution number 5860 .

\section{References}

Austin Jr., J.A., 1997. Continental terraces hold clues to the generation and preservation of the stratigraphic record. EOS 78, 1-2.

Austin, J.A., Fulthorpe, C.S., Mountain, G.S., Orange, D.L., Field, M.E., 1996. Continental-margin seismic stratigraphy: assessing the preservation potential of heterogeneous geological processes operating on continental shelves and slopes. Oceanography 9, 173-177. 
Austin, J.A., Christie-Blick, N., Malone, M., 1997. Ocean Drilling Program Leg 174A Preliminary Report: Continuing the New Jersey Mid-Atlantic Sea-Level Transect. Ocean Drilling Program, College Station, TX, 73 pp.

Berger, W.H., Winterer, E.L., 1971. Plate stratigraphy and the fluctuating carbonate line. In: Hsü, K.J., Jenkyns, H.C. (Eds.), Pelagic Sediments on Land and under the Sea. Int. Assoc. Sedimentol. Spec. Publ. 1, 11-48.

Berggren, W.A., Kent, D.V., Swisher, C.C., Aubry, M.-P., 1995. A revised Cenozoic geochronology and chronostratigraphy. In: Berggren, W.A., Kent, D.V., Aubry, M.-P., Hardenbol, J. (Eds.), Geochronology, Time Scales and Global Stratigraphic Correlation. Soc. Econ. Paleontol. Mineral. Spec. Publ. 54, 129-212.

Diebold, J.B., Stoffa, P.L. et al., 1988. A large aperture seismic experiment in the Baltimore Canyon Trough. In: Sheridan, R.E., Grow, J.A. (Eds.), The Atlantic Continental Margin. The Geology of North America, Vol. I-2, U.S. Geological Society of America, Boulder, CO, pp. 387-398.

Farre, J.A., 1985. The Importance of Mass-wasting Processes on the Continental Slope. Ph.D. Dissertation, Columbia Univ., New York, 200 pp.

Fowler, S., McKenzie, D.P., 1989. Gravity studies of the Rockall and Exmouth Plateau using SEASAT altimetry. Basin Res. 2, 27-34.

Fulthorpe, C.S., Austin, J.A., 1998. The anatomy of rapid margin progradation: three-dimensional geometries of Miocene clinoforms offshore New Jersey. Am. Assoc. Pet. Geol. Bull. 82, 251-273.

Greenlee, S.M., Moore, T.C. 1988. Recognition and interpretation of depositional sequences and calculation of sea-level changes from stratigraphic data - offshore New Jersey and Alabama Tertiary. In: Wilgus, C.K., Hastings, B.S., Kendall, C.G.St.C., Posamentier, H.W., Ross, C.A., Van Wagoner, J.C. (Eds.), Sea-Level Changes: An Integrated Approach. Soc. Econ. Paleontol. Mineral. Spec. Publ. 42, 329-353.

Greenlee, S.M., Shroeder, F.W., Vail, P.R., 1988. Seismic stratigraphic and geohistory analysis of Tertiary strata from the Continental Shelf off New Jersey; calculation of eustatic fluctuations from stratigraphic data. In: Sheridan, R.E., Grow, J.A. (Eds.), The Atlantic Continental Margin. The Geology of North America Vol. I-2, Geol. Soc. Am., Boulder, CO, pp. 437-444.

Greenlee, S.M., Devlin, W.J., Miller, K.G., Mountain, G.S., Flemings, P.B., 1992. Integrated sequence stratigraphy of Neogene deposits, New Jersey continental shelf and slope: comparison with the Exxon model. Geol. Soc. Am. Bull. 104, 1403-1411.

Grow, J.A., Klitgord, K.D., Schlee, J.S., 1988. Structure and evolution of Baltimore Canyon Trough. In: Sheridan, R.E., Grow, J.A. (Eds.), The Atlantic Continental Margin. The Geology of North America, Vol. I-2, U.S. Geological Society of America, Boulder, CO, pp. 269-290.

Haq, B.U., Hardenbol, J., Vail, P.R., 1987. Chronology of fluctuating sea levels since the Triassic (250 million years ago to Present). Science 235, 1156-1167.

Haq, B.U., Hardenbol, J., Vail, P.R., 1988. Mesozoic and Ceno- zoic chronostratigraphy and cycles in sea level change. In: Wilgus, C.K., Hastings, B.S., Kendall, C.G.St.C., Posamentier, H.W., Ross, C.A., Van Wagoner J.C. (Eds.), Sea-Level Changes: An Integrated Approach. Soc. Econ. Paleontol. Mineral. Spec. Publ. 42, 71-108.

Holbrook, W.S., Keleman, P.B., 1993. Large igneous province on the U.S. Atlantic margin and implications for magmatism during continental breakup. Nature 364, 433-436.

Karner, G.D., 1991. Sediment blanketing and the flexural strength of extended continental lithosphere. Basin Res. 3, 177-185.

Katz, M.E., Miller, K.G., 1996. Eocene to Miocene oceanographic and provenance changes in a sequence stratigraphic framework: benthic foraminifers of the New Jersey margin. Proc. ODP, Sci. Results 150, 65-96.

Keen, C.E., Beaumont, C., 1990. Geodynamics of rifted continental margins. In: Keen, M.J., Williams, G.U. (Eds.), Geology of the Continental Margin of Eastern Canada. Geological Survey of Canada, Geology of Canada 2, pp. 393-472.

Klitgord, K.D., Poag, C.W., Schneider, C.M., North, L., 1994. Geophysical database of the east coast of the United States northern Atlantic margin: cross sections and gridded database (Georges Bank basin, Long Island platform, and Baltimore Canyon trough). U.S. Geol. Surv. Open-File Rep. 94-637, 189 pp.

Kominz, M.A., 1984. Oceanic ridge volumes and sea-level change - an error analysis. In: Schlee, J.S. (Ed.), Interregional Unconformities and Hydrocarbon Accumulation. Am. Assoc. Pet. Geol. Mem. 36, 37-58.

Kooi, H., Cloetingh, S., Burrus, J., 1992. Lithospheric necking and regional isostasy at extensional basins, 1 . Subsidence and gravity modeling with an application to the Gulf of Lions margin (SE France). J. Geophys. Res. 97, 17553-17572.

Kuehl, S.A., Nittrouer, C.A., DeMaster, D.J., 1986. Nature of sediment accumulation on the Amazon Continental Shelf. Cont. Shelf Res. 6, 209-225.

Kuehl, S.A., Hariu, T.M., Moore, W.S., 1989. Shelf sedimentation off the Ganges-Brahmaputra river system: evidence for sediment by-passing to the Bengal Fan. Geology 17, 11321135.

Lavier, L., Steckler, M.S., 1997. The effect of sedimentary cover on the flexural strength of continental lithosphere. Nature 389, 476-479.

Lawrence, D.T., Doyle, M., Aigner, T., 1990. Stratigraphic simulation of sedimentary basins: concepts and calibration. Am. Assoc. Pet. Geol. Bull. 74, 273-295.

Lorenzo, J.M., Hesselbo, S.P., 1996. Seismic-to-well correlation of seismic unconformities at Leg 150 continental slope sites. Proc. ODP, Sci. Results 150, 283-292.

Miller, K.G., Mountain, G.S., 1994. Global sea-level change and the New Jersey margin. Proc. ODP, Init. Rep. 150, 11-20.

Miller, K.G., Feigenson, M.D., Wright, J.D., Clement, B.M., 1991. Miocene isotope reference section, Deep Sea Drilling Project Site 608: an evaluation of isotope and biostratigraphic resolution. Paleoceanography 6, 33-52.

Miller, K.G., Aubry, M.-P., Browning, J.V. et al., 1994. Proc. ODP, Init. Rep. 150X. College Station, TX, 59 pp. 
Miller, K.G., Liu, C., Feigenson, M.D., 1996. Oligocene to middle Miocene Sr-isotopic stratigraphy of the New Jersey continental slope. Proc. ODP, Sci. Results 150, 97-114.

Miller, K.G., Browning, J.V., Pekar, S.F., Sugarman, P.J., 1997. Cenozoic evolution of the New Jersey coastal plain: changes in sea level, tectonics, and sediment supply. Proc. ODP, Sci. Results 150X, 361-373.

Miller, K.G., Mountain, G.S., Browning, J.V., Kominz, M., Sugarman, P.J., Christie-Blick, N., Katz, M.E., Wright, J.D., 1998. Cenozoic global sea level, sequences, and the New Jersey transect: Results from coastal plain and continental slope drilling. Rev. Geophys., in press.

Moore, T.C., Loutit, T.S., Greenlee, S.M., 1987. Estimating short-term changes in sea level. Paleoceanography 2, 625637.

Mountain, G.S., Tucholke, B.E., 1985. Mesozoic and Cenozoic geology of the U.S. Atlantic slope and rise. In: Poag, C.W. (Ed.), Geologic Evolution of the United States Atlantic Margin. Van Nostrand Reinhold, New York, pp. 293-341.

Mountain, G.S., Miller, K.G., Blum, P., et al. (Eds.), 1994. Proc. ODP, Initial Reports 150. College Station, TX (Ocean Drilling Program), 885 pp.

Mountain, G.S., Damuth, J.E., McHugh, C.M.G., Lorenzo, J.M., Fulthorpe, C.S., 1996a. Origin, reburial, and significance of a middle Miocene canyon, New Jersey continental slope. Proc. ODP, Sci. Results 150, 283-292.

Mountain, G.S., Miller, K.G., Blum, P., Poag, C.W., Twichell, D.C. (Eds.), 1996b. Proc. ODP, Sci. Results 150. College Station, TX (Ocean Drilling Program), 493 pp.

Nittrouer, C.A., Kravitz, J.H., 1995. Integrated continental margin research to benefit ocean and earth sciences. EOS 76, 121-126.

Nittrouer, C.A., Kuehl, S.A. (Eds.), 1995. Geological Significance of Sediment Transport and Accumulation on the Amazon Continental Shelf. Mar. Geol. 125, 399 pp.

Nittrouer, C.A., Kuehl, S.A., Figueiredo, A.G., Allison, M.A., Sommerfield, C.K., Rine, J.M., Faria, L.E.C., Silveira, O.M., 1996. The geological record preserved by Amazon shelf sedimentation. Cont. Shelf Res. 16, 817-841.

Nummedal, D., Riley, G.W., Templet, P.L., 1993. High-resolution sequence architecture: a chronostratigraphic model based on equilibrium profile studies. In: Posamentier, H.W., Summerhayes, C.P., Haq, B.U., Allen, G.P. (Eds.), Sequence Stratigraphy and Facies Associations. Int. Assoc. Sedimentol. Spec. Publ. 18, 55-68.

Olsson, R.K., Gibson, T.G., Hansen, H.J., Owens, J.P., 1988. Geology of the northern Atlantic coastal plain: Long Island to Virginia. In: Sheridan, R.E., Grow, J.A. (Eds.), The Atlantic Continental Margin. The Geology of North America, Vol. I-2, U.S. Geological Society of America, Boulder, CO, pp. 87105.

Owens, J.P., Bybell, L.M., Paulachok, G., Ager, T.A., Sugarman, P.J., Gonzalez, V.M., 1988. Stratigraphy of the Tertiary sediments in a 945 foot $(288 \mathrm{~m})$ corehole near May's Landing in the southeastern New Jersey Coastal Plain. U.S. Geol. Surv. Prof. Pap. 1484, 39 pp.

Pazzaglia, F.J., 1993. Stratigraphy, petrography, and correlation of the late Cenozoic middle Atlantic coastal plain deposits: implications for late-stage passive margin geologic evolution. Geol. Soc. Am. Bull. 105, 1617-1634.

Pazzaglia, F.J., Brandon, M.T., 1994. Macrogeomorphic evolution of the post-Triassic Appalachian mountains determined by deconvolution of the offshore basin sedimentary record. Basin Res. 8, 255-278.

Pekar, S., Miller, K.G., 1996. New Jersey Oligocene 'Icehouse' sequences (ODP Leg 150X) correlated with global $\delta^{18} \mathrm{O}$ and Exxon eustatic records. Geology 24, 567-570.

Pirmez, C., Pratson, L.F., Steckler, M.S., 1998. Clinoform development by advection-diffusion of suspended sediment: modeling and comparison to natural systems. J. Geophys. Res. 103, 24141-24157.

Poag, C.W., 1985. Geologic Evolution of the United States Atlantic Margin. Van Nostrand Reinhold, New York, 383 pp.

Poag, C.W., Schlee, J.S., 1984. Depositional sequences and stratigraphic gaps on submerged U.S. Atlantic margin. In: Schlee, J.S. (Ed.), Interregional Unconformities and Hydrocarbon Accumulation. Am. Assoc. Pet. Geol. Mem. 36, 165182.

Poag, C.W., Sevon, W.D., 1989. A record of Appalachian denudation in postrift Mesozoic and Cenozoic sedimentary deposits of the U.S. middle Atlantic continental margin. Geomorphology 2, 119-157.

Posamentier, H.W., Jervey, M.T., Vail, P.R., 1988. Eustatic controls on clastic deposition, I. Conceptual framework. In: Wilgus, C.K., Hastings, B.S., Kendall, C.G.St.C., Posamentier, H.W., Ross C.A., Van Wagoner J.C. (Eds.), Sea-Level Changes: An Integrated Approach. Soc. Econ. Paleontol. Mineral. Spec. Publ. 42, 109-124.

Poulsen, C.J., Flemings, P.B., Robinson, R.A.J., Spinelli, G., Miller, K., 1996. Variability of shore-normal relative sea level curves and sediment accumulation patterns of migrating deltas. Geol. Soc. Am. Progr. Abstr., A-63.

Reynolds, D.J., Steckler, M.S., Coakley, B.J., 1991. The role of the sediment load in sequence stratigraphy: the influence of flexural isostasy and compaction. J. Geophys. Res. 96, 69316949.

Ross, W.C., Halliwell, B.A., May, J.A., Watts, D.E., Syvitski, J.P.M., 1994. Slope readjustment: a new model for the development of submarine fans and aprons. Geology 22, 511514.

Schlee, J.S., 1981. Seismic stratigraphy of the Baltimore Canyon trough. Am. Assoc. Pet. Geol. Bull. 65, 26-53.

Schroeder, F.W., Greenlee, S.M., 1993. Testing eustatic curves based on Baltimore Canyon Neogene stratigraphy; an example application of basin-fill simulation. Am. Assoc. Pet. Geol. Bull. 77, 638-656.

Sclater, J.G., Christie, P.A., 1980. Continental stretching: an explanation of the post Mid-Cretaceous subsidence of the Central North Sea basin. J. Geophys. Res. 85, 3711-3739.

Shackleton, N.J., Kennett, J.P., 1975. Paleotemperature history of the Cenozoic and the initiation of Antarctic glaciation, oxygen and carbon isotope analyses in DSDP sites 277, 279, and 281. DSDP, Init. Rep. 29, 743-755.

Sheridan, R.E., Grow, J.A., Klitgord, K.C., 1988. Geophysical 
data. In: Sheridan R.E., Grow, J.A. (Eds.), The Atlantic Continental Margin. The Geology of North America, Vol. I-2, U.S. Geological Society of America, Boulder, CO, pp. 177-195.

Spinelli, G., Nelson, S.E., Flemings, P.B., Robinson, R., Hoover, A., Hotinski, R., Poulsen, C., 1998. 'Strata' modeling of the Neogene in Baltimore Canyon. Soc. Econ. Paleontol. Mineral. Mem. 63, in press.

Steckler, M.S., Reynolds, D.J., Coakley, B.J., Swift, B.A., Jarrard, R.D., 1993. Modeling passive margin sequence stratigraphy. In: Posamentier, H.W., Summerhayes, C.P., Haq, B.U., Allen, G.P. (Eds.), Sequence Stratigraphy and Facies Associations. Int. Assoc. Sedimentol. Spec. Publ. 18, 19-41.

Steckler, M.S., Seranne, M., Lavier, L., 1995. From carbonate ramps to clastic progradation: morphology and stratigraphy of continental margins during Tertiary global change. EOS 76, S188.

Steckler, M.S., Mountain, G.S., Miller, K.G., Christie-Blick, N., 1996a. Reconstructing the geometry of Tertiary sequences on the New Jersey passive margin by 2-D backstripping: the interplay of sedimentation, eustasy and tectonics. Geol. Soc. Am. Progr. Abstr., A-63.

Steckler, M.S., Syvitski, J., Swift, D.J.P., Goff, J., Niedoroda, A.W., 1996b. Stratigraphic modeling of continental margins. Oceanography 9, 183-188.

Steckler, M.S., Watts, A.B., Thorne, J.A., 1988. Subsidence and basin modeling at the U.S. Atlantic passive margin. In: Sheridan, R.E., Grow, J.A. (Eds.), The Atlantic Continental Margin. The Geology of North America, Vol. I-2, U.S. Geological Society of America, Boulder, CO, pp. 399-416.

Vail, P.R., Audemard, F., Bowman, S.A., Einsele, G., Perez-Cruz, G., 1991. The stratigraphic signatures of tectonics, eustasy and sedimentation. In: Einsele, G., Ricken, W., Seilacher, A. (Eds.), Cycles and Events in Stratigraphy. Springer, Berlin, pp. 617-659.

Van Wagoner, J.C., Mitchum, R.M., Campion, K.M., Rahmanian, V.D., 1990. Siliciclastic sequence stratigraphy in well logs, cores and outcrops. Am. Assoc. Pet. Geol., Methods in Exploration Series 7, 55 pp.

Watts, A.B., 1988. Gravity anomalies, crustal structure and flexure of the lithosphere at the Baltimore Canyon Trough. Earth Planet. Sci. Lett. 89, 221-238.

Watts, A.B., Thorne, J.A., 1984. Tectonics, global changes in sea-level and their relationship to stratigraphic sequences at the U.S. Atlantic continental margin. Mar. Pet. Geol. 1, 319339.

Wright, L.D., Wiseman, W.J., Yang, Z.-S., Bornhold, B.D., Keller, G.H., Prior, D.B., Suhayda, J.N., 1990. Processes of marine dispersal and deposition of suspended silts off the modern mouth of the Huanghe (Yellow River). Cont. Shelf Res. 10, 1-40. 